International Journal of English Literature and Social Sciences
Vol-6, Issue-2; Mar-Apr, 2021

\title{
Depiction of Psychological through Supernatural: A Reading of Edgar Allan Poe's Selected Short Stories
}

\author{
Rincy Mathew
}

Department of English Language and Literature Mahatma Gandhi University, Kottayam, Kerala, India

Received: 17 Jun 2020; Received in revised form: 15 Sep 2020; Accepted: 01 Jan 2021; Available online: 28 Apr 2021

(C)2021 The Author(s). Published by Infogain Publication. This is an open access article under the CC BY license

(https://creativecommons.org/licenses/by/4.0/).

\begin{abstract}
This paper analyses the representation of psychology by the supernatural in Edgar Allan Poe's fiction which exposes his tormented and sometimes neurotic obsession with death and violence and his preoccupation regarding the abandonment of women. The various literary devices and themes frequently used by Poe in representing thus are discussed as major subcategories. And for this case I make use of Poe's three different short stories namely"The Fall of the House of Usher", "The Black Cat", and "Morella". Poe had the aid of the pseudo-sciences of the time: mesmerism, phrenology, and other efforts to explore what we today call the subconscious. In the area between waking and sleeping, between life and death, he found the senses most alert, the emotions least inhibited. Insanity, telepathy, and other abnormal or unusual states of the mind became instruments of his deliberately overwrought mind. This paper is an analysis of how the psychological acuity of his stories and their impeccable concision and unity set a model and a standard that few have equaled and none have surpassed when it comes to the macabre fiction.
\end{abstract}

Keywords-Abject, Grotesque, Uncanny.

\section{INTRODUCTION}

"The oldest and strongest emotion of mankind is fear, and the oldest and strongest kind of fear is the fear of the unknown", is the opening sentence of H. P. Lovecraft's treatise "Supernatural Horror in Literature"(1927) and in its somewhat flamboyant fashion it enunciates a central principle governing what might be called the metaphysics of supernatural fiction - its emphasis of the unknown. The works of Edgar Allan Poe revolutionized and transformed supernatural and psychological horror fiction in a profound way so that it could be said that the genre only began with him. Poe keenly analyzed the psychology of fear, and it was manifested in the intense emotive power of narratives. Poe focuses on horror, terror, the supernatural, and what would be termed as psychological suspense. This paper is an analysis of what all personal and the most dustiest corners of a human heart can contribute to the development of horror fiction beyond things that go bump in the night. It manifests how the inner human emotions such as fear, guilt, insecurity and so on bring out the most creepiest external experiences of the macabre in Poe's fiction.

The first section introduces the characteristics of gothic literature, gives a brief note on the author, his unique way of writing. The related key terms are also explained. The second section analyses the short stories as a medium in which the psychology being represented by the supernatural. The various literary devices and themes frequently used by Poe in representing thus are discussed as major subcategories.

\section{POE'S TASTE ON THE MACABRE}

The history of the supernatural in literature, even if it can be conceived to have its root in the oldest literature known to humanity - Gilgamesh, The Odyssey - really had its origin as a concrete genre in the eighteenth century, when Horace Walpole's The Castle of Otranto (1764) triggered the emergence of the Gothic novel as a popular literary form. Supernatural fiction is a very comprehensive term which may be applied to any sort of story which in some way makes use of ghosts, ghouls, specters, apparitions, poltergeists, good and evil spirits and things that go bump in the night; not to mention magic, witchcraft, marvels, talismans, the eerie atmosphere and the presence of the uncanny; anything supernormal, and beyond sensory 
perception; what makes the flesh creep and the hair stand on; the 'spooky', the numinous; that which conveys the sense of 'preternatural' (to use Coleridge's word) powers.

Edgar Allan Poe (1809-1849), the pioneer of the American Romantic movement used his Gothic interests to create fiction characterized of supernatural psychology. On surprisingly few occasions he defended his taste on macabre, chiefly as a quest for imaginative expansion. That pregnant line "I maintain that terror is not of Germany, but of the soul" (n. p.) is as precise an

indication as anyone could explore the psychology of fear in his tales of terror, and his ability to do so with the most consummate skill and emotive power is what distinguishes his work from all that went before and a great proportion of what came after.

He classified his tales as 'grotesque', 'arabesque', and 'ratiocinative' to indicate variations in his intentions. The 'arabesque' is those in which horror or other emotion in violent suspense gives the tale its power; in the 'grotesque' tales the effect is achieved by a grim and ironic humour; in the 'ratiocinative' the effect comes from the use of rational analysis in reconstructing a series of events in the best manner of association psychology. All three methods were developed rather than invented by Poe, but his careful study and systematic use of them made him the master of a new form, 'the short story of psychological effect'.

The usage of anything uncanny contributed to the gothic atmosphere of Poe's short stories. Sigmund Freud referred the German word unheimlich as obviously the opposite of heimlich, heimisch, meaning 'familiar', 'native', 'belonging to the home'; and we are tempted to conclude that what is 'uncanny' is frightening precisely because it is not known and familiar. Naturally not everything which is new and unfamiliar is frightening, howeve; the relation cannot be inverted. We can only say that 'what is novel' can easily become frightening and uncanny; some new things are frightening but not by all means. Something has to be added to what is novel and unfamiliar to make it uncanny. Recurrence of the same situations, things and events, will perhaps not appeal to everyone as a source of uncanny feeling. The phenomenon is undoubtedly, subject to certain conditions and combined with certain circumstances, such as premonitions, duality in the behaviour etc. Which arouse an uncanny feeling, which recalls that sense of helplessness sometimes experienced in dreams.

'Abject' refers to anything 'wretched' or 'lacking all pride'. By its very nature, the Gothic contains elements of 'uncanny' and 'abject', although it maintains a separate and very distinct character. The term 'the abject' was coined by the psychoanalyst Julia Kristeva in her seminal essay entitled Powers of Horror: An Essay on Abjection. Abjection is primarily concerned with societal taboos surrounding the materiality of the body, and the horror that arises from exposure to bodily excretions such as blood, pus, feces. For example, the horror associated with blood is a central theme to Bram Stoker's Dracula, the classic Victorian Gothic novel in which the legend of the vampire is powerfully invoked. In Powers of Horror, Kristeva classifies the corpse, we are forced to address our own mortality and inevitable corruption of our own bodies.

'Grotesque' is another terminology related to the Gothic. The term 'Grotesque' originated in the ancient Roman period and relates to fanciful, decorative flourishes in art and architecture. Grotesque art involves the fantastic, ugly, and bizarre, and its subjects are frequently mythological creatures and other strange, physically malformed monsters. The bizarre, anthropomorphic creatures that populate Lewis Carroll's children novel Alice's Adventures in Wonderland are a primary example of 'the grotesque' in literature.

Combining all these the true spirit of Poe's fiction is marked in the words of Paul March Russell, "Edgar Allan Poe who, unencumbered by the props of medieval history, redefined the form by translating its conventions to the American landscape and by concentrating more upon the psychological effects of horror, especially the depths of guilt and madness within the legacy of Puritanism. Poe imports the Gothic conventions of degenerate aristocrats, decaying mansions, burial chambers and sinister women..." (192). Russell's views are spot on when he states that "...his (Poe) Gothic horrors explored the darker recesses of the human psyche in order to understand more fully what it meant to be human." (196)

\section{REPRESENTATION OF THE PSYCHOLOGICAL IN THE SUPERNATURAL ELEMENTS OF POE'S SHORT STORIES}

Poe is rightly hailed for his works of horror and 'Gothic' literature, yet there are some important qualities which set apart and make it uniquely the art of Edgar Allan Poe. He experiments the supernatural to represent the psychological aspects. The constant themes and literary devices that Poe implemented in his short stories are discussed as subcategories.

3.1 'The synthesis of supernatural and psychology'. The supernatural refers to forces and phenomena imagined to exist beyond ordinary scientific measurement. Meanwhile psychology is concerned with the spiritual, emotional, and mental lives of man and psychological fiction relegates plot and action to a secondary position. As Kathryn VanSpanckeren refers, Edgar Allan Poe believed that strangeness was an essential ingredient of beauty, and his writing is often exotic. VanSpanckeren states, "Poe shares a darkly metaphysical vision mixed with elements of realism" (40).This executed literary feature present the supernatural 
elements in the story in such a way that they appear real to the reader. This can either be through psychological relevance of settings or reliability of the characters. Poe arguably achieves the synthesis of psychology and the supernatural most effectively in "The Fall of the House of Usher". When the narrator states "... with the first glimpse of the building, a sense of insufferable gloom pervaded my spirit" (Poe, 97), we find a mentally disturbed man within the view of the uncanny House of Usher. A sort of uneasiness evoked in the reader due to the landscape features like bleak walls, vacant eye like windows, white trunk of decayed trees. These features impose on him/her a rising horror effect. As the reader tempts to rely on the plot visioned through the narrator, again the readers are affirmed by the 'trustworthy' narrator when he rethinks rationally on the cause of his instability in the contemplation of the House of Usher. And the conclusion to which he arrives indicates the underlying superstition in the narrator, "...there are combinations of very simple natural objects which have the power of thus affecting us" (98). thus here in the story, the supernatural elements such as Madeline's apparent telekinesis appear real to the reader as they are related by a reliable first person narrator. The psychological relevance of settings in the phrases like "soundless day", "passing alone", "singularly dreary" points to the 'solitary' mood which prevails around the mansion. Roderick and Madeline who confine to themselves are represented through these isolated premises and the House itself.

The deliberately capitalized primary letter personifies the grotesque mansion to the lonely and sickly Roderick himself, and so the narrator refers the House as 'mansion of gloom' and the windows as the 'eye of a scrutinizing observer'. Referring to this Michael Fabre says, “The Usher family and their mansion are analogous - crumbling from within, stained with time..." (n. p.) Also a very common element of Poe's stories is how the title of the story refers to the definite article. Here the subject of the title is made more specific by using "The" since it refers to the "Fall" as being unique. The grotesque environment of the House of Usher, such as the Gothic archway, carvings of the vaulted and fretted ceilings, sombre tapestries of walls, ebon blacknessof floor, phantasmagoric armorial trophies, comfortless and antique furniture etc. These descriptions of the House indirectly refer to its reserve, introvert, mysterious, and dreadful residents. Roderick's song "The Haunted Palace" (105-107) alludes to mental deterioration and the psychological effects of isolation. 'Banners yellow' clearly points to the hair where 'glorious' and 'golden' referring to Roderick's aristocratic lineage. The eyes are 'two luminous windows'; the teeth and lips are 'pearl and ruby', all describing his physical appearance. The secluded and unhappy mind of the protagonist is picturised in the stanzas V-VI, and here Poe has successfully used the supernatural to represent the psychological. The depressing loneliness of Roderick is equated with 'evil things, in robes of sorrow' adversely affecting his inherent mind, i.e., 'the monarch's high estate'. the 'troop of echoes' becomes a 'discordant melody' meaning harmonious thought becomes cacophonous madness. Furthermore, the narrator relates the collapse of the mansion with Roderick's own demise. The significance of Roderick's art is also a matter of discussion. There may be a question arising in the minds of reader regarding the function of Roderick's art, which is substantiated by Gerald M. Garmon in the article, "Roderick Usher: Portrait of the Madman as an Artist". he argues that Roderick's art contributes greatly to the definition of his character, pointing directly to the paradox that Usher's heredity and environment endow him with a hypersensitivity that enables him to be an artist seeking freedom and individuality but at the same time doom such endeavors to failure. Again those paintings which the

narrator describes as "pure abstractions" seem to be intended to paint the horror of annihilation which the House poses, but which Roderick cognitively understands only vaguely. Garmon mentions, "This painting, seen as an attempt to communicate with the narrator, suggests that Roderick very likely doubts his own sanity and is trying to use the narrator for a standard of rational thinking (n. p.).

Poe accomplishes the synthesis of psychology and supernatural deftly in "The Black Cat" through providing facts and superstitions on supernormal and unending revenge. In the beginning portion, we find the narrator weaving the upcoming plot through his comment on his wife's superstitious belief that black cats are 'witches' in disguise. This statement is deliberately chosen to be used since it is the primary appalling and forecasting hint marked in the mind of an active reader regarding the unfolded thread of story.

Further the narrator plucks out one of Pluto's (his pet) eye in a fit of anger. Here loss of one eye again indicates the application of the supernatural since it is the most uncanny image. Sigmund Freud states that, regarding the psychoanalytic experiences, fear of damaging or losing one's eyes is a terrible one and no physical injury is so much dreaded as an injury to eye. It is often a substitute for the dread of being castrated. Also the horror in "The Black Cat" is derived from the sudden transformation and cruel act which accompanies it. In this story the fur of the reincarnated cat symbolizes the supposed suppressed guilt that drives him insane and causes him to murder his wife. In "Morella" the narrator whom the reader comes across after the birth of their daughter is found to be confused and aghast at the gleaming passion and wisdom of the infant when he says, "all this became evident to my appalled senses, when I could no longer hide it from my soul..." As the child is Morella herself, reader here recognizes the chief anxiety of Gothic which is possession. Through this the 
personal identity is dismembered, i.e. body is invaded. Here the narrator is found to be in great dilemma whether to accept or reject

his daughter. He loves and cares for his daughter meanwhile disregards and fears her on her astonishing resemblance with his dead wife. Such contradictory fancy is explained by Paul March Russell as "the projection of internal conflicts - the tension between the reasoning ego and the irrational id - so that self-identity is rendered uncanny: the individual is no longer at home with him/herself but is a stranger" (194). Russell states that here Gothic fiction presents the self as split into subject and object, each desiring and fearing the other, each perpetually sliding into one another.

There are analyses regarding even the possible origin of the name 'Morella'. 'Morel' is the name of black nightshade, poisonous weed from which the drug belladonna is derived. It occurs in Presburg (now Bratislava), a reputed home of black magic where Morella is said to have received her education. Thus the name itself presents the collective extraordinary mood prevailed in the story. Referring hallucination and supernatural customs even in the slightest details is a premeditated move by the author for not to escape the intensity of horror inflicted upon the reader.

\section{2 'Madness'}

Madness is another contemporary concern and a frequent theme in Poe's works. Supernatural claims assert phenomena beyond the realm of scientific understanding, and may likewise be in direct conflict with scientific concepts of possibility. Supernatural is often scientifically justified on the basis of an unstable psychology or overwrought mind. Poe's genius was often depicted as a symptom of "madness" of a "tormented artist". As for Robert Giddings, "Poe seems to have been particularly fascinated by the schizophrenic group of illness, marked by a disintegration of thought processes, hallucination, and an unrealistic and wholly subjective relationship with the outside world, based on fantasy" (55). Further he details the classification of these schizophrenic disorders which involve disturbances of thought, emotions and contacts with reality (employed by Poe in his works) by Andrew Crowcroft.

Such disorders named Simple are characterized by lack of emotional depth, other-worldliness, isolation and a lack of activity, a gradual diminution of the use of inner resources and a retreat into increasingly stereotyped patterns of behaviour. When it renamed as Hebephrenia it is characterized by shallow and incongruous emotional responses which seem foolish, bizarre and often involve illusions and hallucinations, voices and strange visual experiences. Catatonia, another category is characterized by striking and unpredictable motor behaviour, trances, rigidity of posture, and loss speech. Meanwhile Paranoia is manifested in feelings of persecution, of being watched and plotted against.

Since the ruined castles and abbeys of European tradition were inappropriate to the new world of North America Poe attempted to Americanize Gothic literature by setting his tales in the uncanny regions of his protagonists' psyches. VanSpanckeren evaluates, "to explore the exotic and strange aspect of psychological processes, Poe delved into accounts of madness and extreme emotion. The painfully deliberate style and elaborate explanation in the stories heighten the sense of the horrible by making events seem vivid and plausible" (42). He often introduces an unreliable narrator who creates an unsettling effect of making the reader feel as if they are conversing with a madman.

In the opening sentence of "The Black Cat" itself, the narrator declares that "I neither expect nor solicit belief" which renders that he himself realizes what he is about to speak beyond customary. "Yet mad am I not - and very surely do I not dream" is a polemical entreaty typically reserved for those who are indeed crazed. The whole incident of the murder of his wife and his pet seems to him as a "series of mere household events", signifying his unstable mind, and evoking a feeling of horror in the reader. His shifting attitude from docility to fiend intemperance commences the appalling plight not only of his pets but also of his spouse. There is probably some underlying exasperation evident in the narrator, for madness succumb a person when he/she represses something in mind. Or even the irresistible supplies like alcohol and drugs too induce such fantasies, and to an extent it seems to be the reason. This preoccupied mindset led to the brutality of the narrator towards Pluto. From here onwards it is this subjugated guilt of his deed that drives the narrator into the recurring evil thoughts and hatred.

An unexpected entry of a similar brute into the madman's home corroborates the terror roving around the wife's prediction of black cats as witches. In the portions where the narrator contemplates on his different projects to conceal the corpse of his wife, we are reminded of the abject themes allied with supernatural. His callous notion of cutting her body into minute fragments, and the corpse found decayed and clotted with gore, arise a feeling of revulsion. The uncanny missing of the beast crop up curiosity. Here becomes the comment of Paul March Russell relevant, "the Gothic imagination turns upon a fear of objects, in particular the individual's anxiety of becoming subject to forces beyond its control" (195). the insane statement with which the narrator ends, "I had walled the monster up within the tomb" horrifies the sensibilities of the reader. And as Robert Giddings states, the feline who denounces the narrator and exposes his crime in "The Black Cat" is undoubtedly his own

conscience personified, but he reacts like one who hears a voice from the other side. 
Elements of madness is evident in "The Fall of House of Usher". As Dr. Leesa Sadasivan opines, when fantasy suppresses reality and the physical self, what results is madness and mental death. Madeline's return and actual death reunites the twin nature of their single being, claiming Roderick as a victim to the terrors that he had anticipated. The true focus of this story is the narrator's reaction to and understanding of these strange events, where fantasy becomes reality to evoke madness. That is why Roderick twice refers to the narrator as 'Madman' in the final scene. The narrator has made a journey into the inscrutable maze of the mind and is nearly destroyed by it. (97).

Theme of divided personality is applied in "The Fall of House of Usher". Roderick and Madeline are twins and seem to be intended to represent two sides of a single personality. Docherty notes, "The theme of catalepsy so severe that it may well be mistaken for death with full attention to its horrific potential in "The Fall of House of Usher", in which Madeline Usher is put living into her tomb, from which she escapes to terrify her brother" (56). The passages in which the narrator in "Morella" describes himself as distraught indicate that he might be mentally unbalanced and therefore unreliable. The expression "My tortured nerves obtained the mastery over my mind" (n.p.) substantiates the same. Similar as in "The Black Cat", one finds no particular reason in the altering attitude of the narrator towards Morella. The line, "joy suddenly faded into horror, and the most beautiful became the most hideous, as Hinnon became Ge-Henna" (n.p.), conveys that the very same erudition that once impressed the narrator, now irritated or even horrified him. Michael J. Cummings analyze this temptation of the narrator to reject his wife may be because of his realization that she is far more intelligent than him. This feeling of inferiority complex may have been repressed in his mind and gradually found an outlet by rejecting her altogether. And as a justification for his deeds he regards his wife's appearance as an uncanny one, "crimson spot steadily upon her cheek, and the blue veins upon the pale forehead became prominent" (n.p.). the narrator's decision to name his child Morella can be examined as his subconscious desire for her death, just as he had for her mother.

Something very interesting regarding the madness in Poe's fiction is the assumption that his own mental state was the leading light to pen such horror piling stories. Gidding suggests that such a tendency in assessing and explicating Poe's work concentrating on his inner psychology began since the publication of Marie Bonaparte's Freudian study The Life and Works of Edgar Allan Poe (1949). Her findings were supported by the categorization of A. Robert Lee who explored the inner- directed Poe being manifested in his own characters. Poe was of course identified as the drug-taker, the alcoholic, the husband of a child-bride, the gambler and celebrant of 'the perverse', and resembling none other than his own tormented figure of Roderick Usher. Thus the two major themes in his stories are his interest in rituals and ceremonies associated with death, and mistaking of life for death, since Poe was personally obsessed with the catatonic condition in which life imitated death.

\section{3 Female Abandonment}

Poe lost both his parents at a very young age and was separated from his brother and sister, Rosalie. Even though he happened to have a step mother, Mrs. Allan, their relationship did not work well. Poe found refuge in the motherly affection of his aunt, Mrs. Maria Clemm and her daughter Virginia, whom he married later. But fate again interfered and Virginia died due to tuberculosis. Poe was now more than ever in a thoroughly abnormal condition of mind and body, for which he tried to find solace in the company of Mrs. Shev. This too survived only for a short span of time. These fears cultivated in him a fear of female abandonment. According to Andrew Hall, “...his creation of some of the most distinctive female characters in fiction can be seen as attempts to reanimate those lost women" (n.p.). His erratic mind, depressed in personal affairs, attempted to establish an all embracing theory of cosmology. Here it's the mental state of Poe itself which is the inspiration for supernatural fiction. This abandonment can be explained on the account of Sigmund Freud's essay "Beyond the Pleasure Principle", proposed by Russell. "Freud observes the masochistic pleasure that a young child takes in repeatedly discarding and retrieving its favourite toy" (187). Thus presence can slide into absence, meaning into insignificance. And this elision is shrouded in the disembodiment of the ghost.

"Morella" can be manifested as the prime example for Poe's fiction of female abandonment. He features the death of a woman and resurrection or communication from beyond the grave. The narrator who is not mentioned to have any other relatives is left only with his wife. Even though her wan fingers and low tone of her musical language become irritable for the narrator and longs for her death, somewhere we find a husband sympathetic to his wife when he utters, "one instant my nature melted into pity" (n.p.). One cannot also affirm that Morella's death completely unmoved the narrator.

Further the narrator is portrayed as an ideal father who dearly loves his daughter addressed by him as "my child" and "my love". But when he suggested the name Morella for his daughter with a "demon urge", there occurs the most abject scene. Kristeva defines abjection in terms ofexcentricity which disturbs identity, system and order. Psychological fragmentation is also mirrored by the alienation of mind from body and one finds the realization of the daughter with the mother here. Allen Tate suggested 
that Morella's rebirth may be her becoming a vampire to wreak vengeance on the narrator.

The death of Madeline in "The Fall of House of Usher" is another indication of female abandonment. The narrator happens to know about the death of Madeline through Roderick. There is a possibility that the lady might had just looked like she is dead, because of her catalepsy. But due to Roderick's gradual fear of losing his sister or his cataleptic mind makes him conclude that she is no more. This can be the outcome of Poe's mental distraught regarding his separation from his sister, Rosalie.

According to Hall, Poe may have felt responsible for the loss of other women in his life too, as it seems those he did not lose to death, but because of his actions. In the three stories, his characters are presented guilty of the abandonment of the women. Roderick who concludes his sister dead, buries her alive in the vault, burdening himself with the guilt. In "The Black Cat", the mad narrator murders his wife in a frenzied state resulting in the further appalling plight. And again it is the narrator's rejection which is responsible for the death of Morella and he did secretly desire for the death of his child too. This spots the author under the shadow of insecurity concerning his very near women.

\section{CONCLUSION}

To sum up, the paper attempts to understand supernatural tales of Edgar Allan Poe as an agency through which he could disclose his own personal insecurities and social anxieties related to madness, disease and death. As Poe is sorted to be a scholar seeking solid elements for his matter, he analyzed on the basic emotion of a person i.e., fear. One may find the genius of this versatile writer when observing the various supernormal aspects exploited to deliver the psychological. It ranges from the settings, dialogues, mindset of the character and to the mentality of Poe himself. Synthesis of supernatural and psychology, madness, and female abandonment are used as frequent themes in Poe's fiction which ultimately gives way to evoke horror feeling in the reader, and also expose the psychology of terror. The paper focuses on how uncanny settings, abject and grotesque images which primarily represent the inner psyche of human mind come together in Poe's fiction in order to lay light on the horror and revulsion that may follow as the result. Limitation concerning the paper is that it is restricted to the exploration of only the above mentioned subcategories in the selected short stories of Edgar Allan Poe. It also focus only in qualitative content analysis rather than any other technique. However, it can add to the existing review of literature. The paper can be considered as a new psychological insight into the interpretations of Poe's fiction.

\section{ACKNOWLEDGEMENTS}

First of all I express my sincere gratitude to God Almighty for all the care and blessings He has abundantly showered me with. I want to express my deep gratitude to my parents who are my constant pillars of support and strength. My heartfelt thanks to the faculty members of the English Department, Baselius College, Kottayam for guiding me throughout the paper. Also my sincere gratitude to the College Library staff members of Baselius College, Kottayam who gave me access to the wide range of books that contributed to the completion of this paper.

\section{REFERENCES}

[1] Fabre, Michael. 'Poe, Lovecraft, and the Revolution in Weird Fiction'. Edgar Allan Poe Society of Baltimore-The Life and Writings of Edgar Allan Poe. Retrieved from <http://www.eapoe.org/index.htm>

[2] Freud, Sigmund. "The Uncanny". Literary Theory: An Anthology. Ed. Julie Rivkin and Michael Ryan. Massachusetts: Blackwell Publishers, 1998. Print.

[3] Garmon, Gerald. 'Roderick Usher: Portrait of the Madman as an Artist'. Poe Studies. Retrieved from <http://www.eapoe.org/pstudies/ps1970/p1972104.htm>

[4] Giddings, Robert. "Poe: Rituals of Life and Death". American Horror Fiction: From Brockden Brown to Stephen King. Ed. Brian Docherty. London: The Macmillan Press Ltd, 1990. Print.

[5] Hall, Andrew. 'The Supernatural Psychology of Edgar Allan Poe'. Spectral Visions. Retrieved from $<$ https://spectralvisions.wordpress.com/>

[6] Poe, Edgar Allan. "The Fall of House of Usher". Blooming Lilacs: An Anthology of American Literature. Ed. Dr. Leesa Sadasivan. Thrissur: Current Books, 2014. Print.

[7] Poe, Edgar Allan. "The Black Cat". Poe stories.com:An Exploration of short stories by E. A. Poe. Retrieved from $<$ http://poestories.com/stories.php>

[8] Poe, Edgar Allan. "Morella". Read book online. Retrieved from <http://www.readbookline>

[9] Russell, Paul March. The Short Story: An Introduction. Edinburgh: Edinburgh University Press Ltd, 2009. Print.

[10] VanSpanckeren, Kathryn. Outline of American Literature. USA: United States Department of State. Print. 